\section{Leaf Gas Exchange Characteristics of Red Raspberry Germplasm in a Hot Environment}

\author{
Eric T. Stafne ${ }^{1}$, John R. Clark ${ }^{2}$, and Curt R. Rom ${ }^{2}$ \\ Department of Horticulture, University of Arkansas, Fayetteville, AR 72701-1201
}

Additional index words. evapotranspiration, heat tolerance, net $\mathrm{CO}_{2}$ assimilation, photosynthesis, Rubus coreanus, $R$. innominatus, $R$. parvifolius, stomatal conductance

\begin{abstract}
Net $\mathrm{CO}_{2}$ assimilation (A), evapotranspiration (ET), and stomatal conductance $\left(g_{\mathrm{s}}\right)$ were determined in two experiments for 14 and 18 raspberry (Rubus sp.) genotypes, respectively, grown in 4 -L containers and exposed to $35^{\circ} \mathrm{C}$ daytime temperatures 2 weeks and 4 weeks after placement in growth chambers. Measurements were taken on two successive leaves on the same primocane between the third and seventh node $(\approx 75 \%$ to 85\% of full leaf expansion). In Expt. 1, selections from Louisiana exhibited higher A (3.10$\left.5.73 \mu \mathrm{mol} \cdot \mathrm{m}^{-2} \cdot \mathrm{s}^{-1}\right)$ than those from Oregon $\left(0.50-2.65 \mu \mathrm{mol} \cdot \mathrm{m}^{-2} \cdot \mathrm{s}^{-1}\right)$. In Expt. 2, the genotype $\times$ time interactions were nonsignificant, and time of measurement did not affect A or ET $(P \leq 0.05)$. Assimilation ranged from 2.08 to $6.84 \mu \mathrm{mol} \cdot \mathrm{m}^{-2} \cdot \mathrm{s}^{-1}$ and varied greatly among genotypes, indicating that diverse $A$ levels exist at high temperatures in raspberry germplasm. NC 296, a selection of $R$. coreanus Miq. from China, and 'Dormanred', a southern-adapted raspberry cultivar with $R$. parvifolius Hemsl. as a parent, had the highest A rates. Evapotranspiration and $g_{\mathrm{s}}$ did not differ among genotypes. Average $g_{\mathrm{s}}$ for all genotypes declined from $234 \mathrm{mmol} \cdot \mathrm{m}^{-2} \cdot \mathrm{s}^{-1}$ in week 2 to $157 \mathrm{mmol} \cdot \mathrm{m}^{-2} \cdot \mathrm{s}^{-1}$ in week 4 . Our findings, coupled with plant performance under hot conditions, can be used to identify potential parental raspberry germplasm for breeding southern-adapted cultivars.
\end{abstract}

Interest in red raspberry (Rubus idaeus L.) in the southern states has increased recently (Clark and Rom, 1997), but the region suffers from a lack of southern-adapted cultivars with commercial quality (Moore, 1997). Currently available cultivars developed outside of the South are not well-adapted for several reasons, including high light intensities and hot summer temperatures (Moore, 1997). Southern Asiatic countries traditionally have been the source of Rubus plant material with tolerance to heat and drought. North American researchers have been the leaders in introducing wild species to the commercial genetic base for incorporation of heat tolerance (Jennings et al., 1991). Unfortunately, commitment to the development of heat-tolerant, commercial-quality cultivars has not been sustained. Considerable efforts (Hull, 1969; Overcash, 1972; Williams, 1950) have proved only mildly successful, but these researchers have generated many selections from their breeding programs. Yet, no efficient proce-

Received for publication 14 June 1999. Accepted for publication 15 Oct. 1999. Published with approval of the Director, Arkansas Agricultural Experiment Station, as manuscript no. 99053 . This paper is a portion of a thesis submitted by Eric T. Stafne. We thank Jim Ballington, Chad Finn, Kim Hummer, and Glen Melcher for providing plant material. The cost of publishing this paper was defrayed in part by the payment of page charges. Under postal regulations, this paper therefore must be hereby marked advertisement solely to indicate this fact.

${ }^{1}$ Former Graduate Assistant. Current address: USDA-ARS, Sugarcane Field Station, HCR, Box 8, Canal Point, FL 33438. e-mail: estafne@ag.gov ${ }^{2}$ Associate Professor. dure exists to identify those selections that have inherited heat tolerance or to determine which species have the most to offer a breeding program. Gas exchange characteristics of Rubus germplasm may indicate adaptation to hot conditions.

Donnelly and Vidaver (1984) reported results on a raspberry selection (BC 72-1-7, a cross of 'Haida' $x$ 'Canby', later released as 'Algonquin') with the maximum rate of $\mathrm{A}$ between 6.3 and $9.5 \mu \mathrm{mol} \cdot \mathrm{m}^{-2} \cdot \mathrm{s}^{-1}$. No studies have evaluated genotype response at high temperatures in the South. A few studies have focused on established cultivars in general, such as 'Amity', 'Autumn Bliss', 'Heritage', 'Meeker', and 'Titan' (Cameron and Hartley, 1989; Fernandez and Pritts, 1994; Goulart, 1989; Hunt et al., 1991; Klauer et al., 1992; Percival et al., 1996; Privé et al., 1997). Cameron and Hartley (1989) examined gas exchange characteristics of 'Amity' leaves after partial defoliation and discovered that A, $g_{s}$, and transpiration increased after one-third or two-thirds of the total leaf area on one leaf were removed. Gas exchange rates reported for whole leaves in this study were $8.9 \mu \mathrm{mol} \cdot \mathrm{m}^{-2} \cdot \mathrm{s}^{-1}$ (A), $99.3 \mathrm{mmol} \cdot \mathrm{m}^{-2} \cdot \mathrm{s}^{-1}\left(g_{\mathrm{s}}\right)$, and $2.6 \mathrm{mmol} \cdot \mathrm{m}^{-2} \cdot \mathrm{s}^{-1}$ (transpiration). In 'Titan' and 'Heritage', Goulart (1989) found that A and $g_{s}$ increased as soil water content increased from deficit to high levels. Hunt et al. (1991) determined that maximum assimilation levels were achieved at 1000 to $1200 \mu \mathrm{mol} \cdot \mathrm{m}^{-2} \cdot \mathrm{s}^{-1}$ photosynthetically active radiation $(P A R)$ when 'Titan' leaflets reached $75 \%$ to $85 \%$ of full expansion. The highest levels of $\mathrm{CO}_{2}$ assimilation were reached from 0700 to $1000 \mathrm{HR}$ in a study conducted by Klauer et al. (1992) on 'Meeker'.

Fernandez and Pritts (1994), Percival et al.
(1996), and Privé et al. (1997) examined gas exchange response to temperature, but response to high temperature was not the major focus of these studies. Fernandez and Pritts (1994) found that gas exchange of primocane leaves on 'Titan' declined as temperature increased from 15 to $40^{\circ} \mathrm{C}$. Assimilation rate at $20^{\circ} \mathrm{C}$ was $\approx 8 \mu \mathrm{mol} \cdot \mathrm{m}^{-2} \cdot \mathrm{s}^{-1}$, whereas at $35^{\circ} \mathrm{C}$ it declined to $\approx 4 \mu \mathrm{mol} \cdot \mathrm{m}^{-2} \cdot \mathrm{s}^{-1}$. Similar results were reported by Percival et al. (1996) for whole-plant A of 'Heritage'. However, Privé et al. (1997) stated that high A and $g_{\mathrm{s}}$ rates were obtained at both warm $\left(\approx 30^{\circ} \mathrm{C}\right)$ and $\operatorname{cool}(\approx 15$ $\left.{ }^{\circ} \mathrm{C}\right)$ temperatures. They also reported a wide range in $g_{s}$ throughout the season; the mean for leaves in the absence of a subtending fruiting or flowering lateral was $159 \pm 110 \mathrm{mmol} \cdot \mathrm{m}^{-2} \cdot \mathrm{s}^{-1}$.

The objectives of this study were to examine gas exchange characteristics among a broad range of genotypes that had not been studied previously and to determine if any expressed qualities contributed to heat tolerance.

\section{Materials and Methods}

Fourteen diverse genotypes from varying origins were used in Expt. 1 (Table 1), and 18 genotypes were used in Expt. 2 (Table 2). Many of these genotypes are native to regions where summer conditions are hot and humid, as in the upper South. These were obtained from the U.S. Dept. of Agriculture, Agricultural Research Service (USDA, ARS) National Clonal Germplasm Repository and the USDA, ARS, Northwest Center for Small Fruit Research, both at Corvallis, Ore., from North Carolina State Univ., and from Glen Melcher, a private Rubus breeder in Louisiana. Plants were potted in 4-L pots in a Universal Mix media (Strong-Lite Hort. Prod., Pine Bluff, Ark.) containing a controlled-release fertilizer (Osmocote 18N-2.6P-9.9K, $14 \mathrm{~g}$ / pot) and grown in the greenhouse for several months until the experiment was initiated. Plants were placed in three $2.13-\mathrm{m}^{2}$ Conviron 3244 growth chambers (Winnipeg, Man., Canada) on 3 July 1998 for Expt. 1 and 22 May 1998 for Expt. 2. Growth chamber temperatures were $35^{\circ} \mathrm{C}$ day (16-h photoperiod) and $25^{\circ} \mathrm{C}$ night to approximate conditions for the southern United States.

Measurements were taken 2 and 4 weeks after placement in the growth chamber with a CIRAS-1 (PP-Systems, Hitchens, Herts, U.K.) portable infrared gas analyzer (IRGA) and Parkinson leaf cuvette $\left(2.5 \mathrm{~cm}^{2}\right)$ on two leaves per primocane. Leaves were at $75 \%$ to $85 \%$ of full expansion at the time of measurement. The air flow rate within the cuvette was set at $200 \mathrm{~mL} \cdot \mathrm{min}^{-1}$ with $350 \mathrm{~mL} \cdot \mathrm{L}^{-1} \mathrm{CO}_{2}$ and $50 \%$ of ambient water vapor. Leaf and chamber temperature were maintained by a thermoconductive peltier plate, set at $35{ }^{\circ} \mathrm{C}$, and measured using an infrared temperature sensor. PAR was maintained between 1000-1500 $\mu \mathrm{mol} \cdot \mathrm{m}^{-2} \cdot \mathrm{s}^{-1}$ during measurements, the reported light saturation level for Rubus (Hunt et al., 1991; Rom and Clark, 1991). Stability in measurement was reached between 1 and 2 min. Plants were watered as needed, and no water stress was experienced prior to or during 
enclosure in the growth chamber. Measurements were taken on the same day of the week between 0800 and $1200 \mathrm{HR}$.

Expt. 1 consisted of one growth chamber containing 14 entries with one plant only of each entry. On each date data from two separate leaf measurements were averaged for both experiments. Analysis of variance was performed using the LSMEANS statement in the MIXED procedure of SAS (Cary, N.C.) for Expt. 2. Proc CORR was used to determine correlations. The experimental design was a randomized incomplete block, with two or three replications (plants) of each of 18 entries. Each growth chamber was considered a block.

\section{Results and Discussion}

For Expt. 1, means from one plant averaged over two times of measurement were generated for A, ET, and $g_{s}$. This provided insight as to the photosynthetic capabilities of previously untested selections and species that could not be included in Expt. 2 because of a shortage of plant material. ORUS selections generally placed low, whereas Louisiana genotypes were among the highest performers, for all dependent variables (Table 1). Rubus innominatus Moore exhibited surprisingly high ET and $g_{\text {s }}$ rates (data not shown) in relation to its low rate of A. 'Dormanred' had a lower A rate than in Expt. 2, perhaps because of later measurement dates or variation among plants used. Melcher 92-3-34 and 96-2-41 are offspring from crosses that include at least one red raspberry parent with heat tolerance. Gas exchange measurements for these genotypes may reflect heat tolerance inherited from the parental material (Hancock et al., 1992). Melcher 93-5-41 is a cross between OR 1030, an Oregon-developed red raspberry selection of uncertain origin (F.J. Lawrence, personal comm.), and $R$. occidentalis L., the North American black raspberry. It displayed lower rates for all variables than did the other Melcher genotypes. This result is consistent with the data for the ORUS selections in both studies.

Interactions between genotype and time of measurement were nonsignificant in Expt. 2. Evapotranspiration and $g_{\mathrm{s}}$ did not differ among genotypes (data not shown). Average stomatal conductance declined from 234 to $157 \mathrm{mmol} \cdot \mathrm{m}^{-2} \cdot \mathrm{s}^{-1}$ from the second to the fourth week. Assimilation varied from a high of 6.84 for NC 296 to a low of $2.08 \mu \mathrm{mol} \cdot \mathrm{m}^{-2} \cdot \mathrm{s}^{-1}$ for ORUS 1728-1 (Table 2). NC296, 'Dormanred', 'Mandarin', and 'Jingu Jeugal' (S. Korean breeding program) displayed the highest A rates. The ORUS series, all siblings, differed both within and among selections, with A varying from 2.08 (ORUS $1728-1$ ) to $4.59 \mu \mathrm{mol} \cdot \mathrm{m}^{-2} \cdot \mathrm{s}^{-1}$ (ORUS 1728-5). Even though all of the ORUS series were selected in Oregon and subjected to identical experimental conditions in this study, the variation expressed was significant.
Fernandez and Pritts (1994) found that primocanes of 3-year-old potted 'Titan' red raspberry plants had A rates of $\approx 4 \mu \mathrm{mol} \cdot \mathrm{m}^{-2} \cdot \mathrm{s}^{-1}$ at $35^{\circ} \mathrm{C}$. Percival et al. (1996) found similar results with whole-plant net $\mathrm{CO}_{2}$ exchange of 'Heritage' red raspberry. The results of our study are similar, as $4 \mu \mathrm{mol} \cdot \mathrm{m}^{-2} \cdot \mathrm{s}^{-1}$ was near the median A rate for the 18 genotypes. However, the wide variation among the genotypes is noteworthy. Keep (1972) noted that wild raspberry populations vary widely in several physiological and morphological traits, such as leafing and flowering times, leaf shape, and spine density. Our findings indicate that variation within Rubus species in gas exchange characteristics is also significant.

Several genotypes in the replicated study were hybrids of $R$. parvifolius, but not the same clones. Rubus parvifolius is reported to be adaptable to high temperature (Moore, 1997). 'Dormanred', a $R$. parvifolius derivative, is adapted to the southern United States, and in this study exhibited a high A rate, especially in comparison with ORUS 1728-1. This high A rate may contribute to the adaptation of 'Dormanred' to high temperature. The wide range in A among the $10 R$. parvifoliusderived genotypes in our study may reflect variation in adaptation of $R$. parvifolius genotypes to high temperature or in their specific combining abilities in hybridizations with other genotypes. It could also reflect the fact that the parents of the ORUS series were selected

Table 1. Genotype, parentage, location where genotype was selected, and assimilation rates (A) of raspberry germplasm at $35^{\circ} \mathrm{C}$ in Expt. 1.

\begin{tabular}{|c|c|c|c|}
\hline Parentage & Location & Genotype & A \\
\hline Bababerry x Dormanred & Louisiana & Melcher 92-3-34 & 5.73 \\
\hline Mandarin x Melcher 94-3-206 & Louisiana & Melcher 96-2-41 & 4.60 \\
\hline Dorsett $\times R$. parvifolius & Mississippi & Dormanred & 3.64 \\
\hline OR $1030 \times R$. occidentalis & Louisiana & Melcher 93-5-41 & 3.10 \\
\hline R. parvifolius $1658-2236 \times$ Tulameen & Oregon & ORUS 1730-4 & 2.65 \\
\hline \multirow[t]{2}{*}{ (R. innominatus O.P.) x O.P. } & N. Carolina & $\mathrm{NC} 405$ & 2.25 \\
\hline & Jiangxi, Japan & R. innominatus (NC 1768) & 1.83 \\
\hline R. parvifolius $1658-2236 \times$ Tulameen & Oregon & ORUS $1730-6$ & 1.73 \\
\hline \multirow[t]{2}{*}{ [NC 86-14-1(R. trivialis Michx.) x Glen Prosen] } & N. Carolina & NC 354 & 1.58 \\
\hline & Japan & R. phoenicolasius Maxim. & 1.58 \\
\hline R. parvifolius $1659-2239 \times$ Tulameen & Oregon & ORUS $1728-2$ & 1.45 \\
\hline R. parvifolius $1659-2239 \times$ Tulameen & Oregon & ORUS $1728-3$ & 1.30 \\
\hline$R$. coreanus $1634-1923 \times$ Meeker & Oregon & ORUS $1725-3$ & 0.55 \\
\hline R. coreanus $1634-1923 \times$ Meeker & Oregon & ORUS 1725-6 & 0.50 \\
\hline
\end{tabular}

Table 2. Genotype, parentage, location where genotype was selected, and assimilation rates (A) of raspberry germplasm at $35^{\circ} \mathrm{C}$ in Expt. 2.

\begin{tabular}{|c|c|c|c|}
\hline Parentage & Location & Genotype & A \\
\hline R. coreanus (RUB 1635 O.P.) & SW China & NC 296 & $6.84 \mathrm{a}^{\mathrm{z}}$ \\
\hline Dorsett $\times R$. parvifolius & Mississippi & Dormanred & $6.42 \mathrm{ab}$ \\
\hline (R. parvifolius $\mathrm{x}$ Taylor) $\mathrm{x}$ Newburgh & N. Carolina & Mandarin & $5.69 \mathrm{a}-\mathrm{c}$ \\
\hline$R$. crataegifolius Bge. & S. Korea & Jingu Jeugal & $5.04 \mathrm{~b}-\mathrm{d}$ \\
\hline NC 177 (R. innominatus O.P.) x Comox & N. Carolina & NC 365 & $4.68 \mathrm{c}-\mathrm{e}$ \\
\hline \multirow{2}{*}{$R$. parvifolius $1659-2239 \times$ Tulameen } & Oregon & ORUS 1728-5 & $4.59 \mathrm{c}-\mathrm{e}$ \\
\hline & Jiangxi, China & R. innominatus & $4.47 \mathrm{c}-\mathrm{f}$ \\
\hline \multirow[t]{2}{*}{ R. parvifolius $1658-2236 \times$ Tulameen } & Oregon & ORUS 1730-5 & $3.98 \mathrm{c}-\mathrm{g}$ \\
\hline & Honshu, Japan & R. parvifolius & $3.73 \mathrm{~d}-\mathrm{g}$ \\
\hline R. parvifolius $1659-2239 \times$ Tulameen & Oregon & ORUS 1728-4 & $3.39 \mathrm{~d}-\mathrm{g}$ \\
\hline R. parvifolius $1658-2236 \times$ Tulameen & Oregon & ORUS $1730-2$ & $3.35 \mathrm{~d}-\mathrm{g}$ \\
\hline \multirow{2}{*}{ R. parvifolius $1658-2236 \times$ Tulameen } & Oregon & ORUS $1730-3$ & $3.32 \mathrm{e}-\mathrm{g}$ \\
\hline & Honshu, Japan & R. illecebrosus Focke & $3.28 \mathrm{e}-\mathrm{g}$ \\
\hline$R$. coreanus $1634-1923 \times$ Meeker & Oregon & ORUS $1725-1$ & $3.15 \mathrm{e}-\mathrm{g}$ \\
\hline R. parvifolius $1658-2236 \times$ Tulameen & Oregon & ORUS 1730-1 & $2.71 \mathrm{fg}$ \\
\hline Sunrise $\mathrm{x}$ Taylor & Maryland & Sentry & $2.60 \mathrm{fg}$ \\
\hline$R$. coreanus $1634-1923 \times$ Meeker & Oregon & ORUS $1725-2$ & $2.58 \mathrm{fg}$ \\
\hline R. parvifolius $1659-2239 \times$ Tulameen & Oregon & ORUS 1728-1 & $2.08 \mathrm{~g}$ \\
\hline
\end{tabular}

${ }^{\mathrm{z}}$ Mean separation by $t$ test, $P \leq 0.05 . \mathrm{n}=$ two to three replicate plants/genotype; two sample leaves/replication. 
under Pacific Northwest rather than Southern conditions. Variation in A among offspring from the cross $R$. parvifolius $\mathrm{x}$ 'Tulameen' (ORUS 1728-1, 1728-4, and 1728-5) is noteworthy. Also, NC 296, ORUS 1725-1, and ORUS $1725-2$, all of which had $R$. coreanus collected from the same Chinese location as a parent, differed considerably. NC 296 was selected in North Carolina, whereas ORUS 1725-1 and 1725-2 were selected in Oregon. This difference in environment could have contributed to the difference in A.

Assimilation had a significant relationship, but was not strongly correlated with either ET $(R=0.52, P \leq 0.0001)$ or $g_{\mathrm{s}}(R=0.46, P \leq$ $0.0001)$. This suggests that at high temperature nonstomatal inhibition of A occurs, as reported previously (Fernandez and Pritts, 1994; Privé et al., 1997). Evapotranspiration was strongly correlated with $g_{\mathrm{s}}$, as was expected $(R=0.95, P \leq 0.0001)$.

Although measurement of a larger range of genotypes would be needed to more precisely quantify the variation in A in red raspberry germplasm, our data indicate that variability in A exists among the genotypes tested. Also, A is inhibited by nonstomatal factors at high temperatures, as evidenced by the correlation data, implying that photosynthetic activity is being controlled by physiological processes unrelated to stomatal function. Photosynthetic mechanisms of woody species can show a high degree of plasticity to temperature variation even within a single population (Tranquillini, 1979). Therefore, net photosynthesis may not be a good indicator of yield or other traits (Elmore, 1980; Zelitch, 1982). The next logi- cal step would be to test the responses of the genotypes at high field temperatures to determine how they compare with those in a controlled environment.

\section{Literature Cited}

Cameron, J.S. and C.A. Hartley. 1989. The influence of leaf : fruit ratio on gas exchange characteristics of red raspberry leaves. Acta Hort. 262:255-258.

Clark, J.R. and C.R. Rom. 1997. Introduction to the workshop: Small fruit breeding for the southern United States: Progress and prospects. Fruit Var. J. 51:133-134.

Donnelly, D.J. and W.E. Vidaver. 1984. Pigment content and gas exchange of red raspberry in vitro and ex vitro. J. Amer. Soc. Hort. Sci. 109:177-181.

Elmore, C.D. 1980. The paradox of no correlation between leaf photosynthetic rates and crop yields, p. 155-167. In: J.D. Hesketh and J.W. Jones (eds.). Predicting photosynthesis for ecosystem models. vol. 2. CRC Press, Boca Raton, Fla.

Fernandez, G.E. and M.P. Pritts. 1994. Growth, carbon acquisition, and source-sink relationships in 'Titan' red raspberry. J. Amer. Soc. Hort. Sci. 119:1163-1168.

Goulart, B.L. 1989. Influence of three soil water levels on micropropagated greenhouse grown red raspberry. Acta Hort. 262:277-283.

Hancock, J.F., K. Haghighi, S.L. Krebs, J.A. Flore, and A.D. Draper. 1992. Photosynthetic heat stability in highbush blueberry and the possibility of genetic improvement. HortScience 27:1111-1112.

Hull, J.W. 1969. Southland red raspberry-A new fruit crop for the South. Fruit Var. Hort. Dig. 23:48.
Hunt, S.K., D.E. Deyton, and C.E. Sams. 1991. The influence of leaf position, age, and environmental factors on net photosynthesis of red raspberry. HortScience 26:69. (Abstr.)

Jennings, D.L., H.A. Daubeny, and J.N. Moore. 1991. Blackberries and raspberries (Rubus). Acta Hort. 290:329-389.

Keep, E. 1972. Variability in the wild raspberry. New Phytol. 71:915-924.

Klauer, S.F., C. Chen, P.F. Foote, and J.S. Cameron 1992. Diurnal photosynthesis and starch deposition in leaves of fruiting and deflowered red raspberry canes. HortScience 27:654. (Abstr.)

Moore, J.N. 1997. Blackberries and raspberries in the southern United States: Yesterday, today, and tomorrow. Fruit Var. J. 51:148-157.

Overcash, J.P. 1972. Dormanred raspberry: A new variety for Mississippi. Mississippi Agr. and For. Expt. Sta. Bul. 793.

Percival, D.C., J.T.A. Proctor, and M.J. Tsujita 1996. Whole-plant net $\mathrm{CO}_{2}$ exchange of raspberry as influenced by air and root-zone temperature, $\mathrm{CO}_{2}$ concentration, irradiation, and humidity. J. Amer. Soc. Hort. Sci. 121:838845.

Privé, J-P., J.A. Sullivan, and J.T.A. Proctor. 1997. Seasonal changes in net carbon dioxide exchange rates of 'Autumn Bliss', a primocanefruiting red raspberry (Rubus idaeus L.). Can. J. Plant Sci. 77:427-431.

Rom, C.R. and J.R. Clark. 1991. Gas exchange characteristics of field-grown 'Shawnee' blackberry. HortScience 26:687-688. (Abstr.)

Tranquillini, W. 1979. Physiological ecology of the alpine timberline. Springer-Verlag, Berlin.

Williams, C.F. 1950. Influence of parentage in species hybridization of raspberries. Proc. Amer. Soc. Hort. Sci. 56:149-156.

Zelitch, I. 1982. The close relationship between net photosynthesis and crop yield. BioScience 32:796-802. 